\title{
Arsenic in the environment-risks and management strategies
}

\author{
Ravi Naidu $\cdot$ Prosun Bhattacharya
}

Received: 16 July 2008/ Accepted: 17 November 2008/Published online: 16 January 2009

(C) Springer Science+Business Media B.V. 2009

\section{Introduction}

Incidences of arsenic (As) poisoning in the Indian subcontinent-where thousands of people are affected by arsenicosis, and millions are potentially at risk-have led to renewed interest in the problem of As throughout the world. Consequently many funding bodies have provided significant support to local and international research teams to assess the extent of the problem and the strategies that are needed to minimise the poisoning of people. This has led to the publication of several articles that give a holistic overview of the dynamics of As in the soil and water environment. There has also been significant interest in the human health risk associated with

\section{R. Naidu $(\bowtie)$}

Cooperative Research Centre for Contamination Assessment and Remediation of Environments (CRC CARE), Salisbury South, P.O. Box 486, Adelaide 5106, Australia

e-mail: ravi.naidu@crccare.com

\section{R. Naidu}

Centre for Environmental Risk Assessment and Remediation, University of South Australia, Mawson Lakes Boulevard, Mawson Lakes, Adelaide 5095, Australia

\section{P. Bhattacharya}

Department of Land and Water Resources Engineering, KTH-International Groundwater Arsenic Research Group, Royal Institute of Technology (KTH), SE-100 44 Stockholm, Sweden the presence of As in the soil and water. Consequently, researchers have been focussing on the exposure pathways associated with As in groundwater. Unfortunately, papers published on the status of As in the soil and water environments and exposure pathways have almost always used a limited number of soil, crop and groundwater samples-often the sample size hardly exceeds 20 . Despite this, reputable journals have continued to publish papers that have led to generalisation of the associated risks based on limited sampling. For this reason, we have focussed our research on sample sizes greater than 100 .

This special issue, entitled "Arsenic in the Environment-Risks and Management Strategies", comprises a wide range of contributions with an aim to present a multi-disciplinary coverage of themes related to the problem of natural As contamination in the environment. These themes include: (1) an overview of the extent of As contamination in southeast Asian perspective; (2) hydrogeochemical constraints of As in groundwater and monitoring with examples from Bangladesh; (3) chemistry and bioavailability of inorganic As in soils; (4) extraction of As species from soils and plants; (5) arsenic speciation and uptake mechanisms of As by plants and (6) assessment of chronic As exposure, associated human health and ecological risks.

The articles included in this special supplement address many of these issues and pave the way through recent findings on the environmental behaviour of As in soil and groundwater systems, in terms 
of occurrence, sources, bioavailability, latest state-ofthe-art methodologies for extraction of As from agricultural matrices, As uptake by plants, human health exposure and associated risk assessment. Besides understanding the fundamental processes of As mobilisation, the authors shed new light on the fate and dynamics of As in the soil environment, including human exposure in Bangladesh. We would like to dedicate this special supplement to our coworker, the late Dr. Shibtosh Roy, who sacrificed his life for the cause of research on As contamination in groundwaters and efforts to mitigate this environmental health disaster in Bangladesh.

\section{Layout of the special supplement}

This special supplement comprises three review articles dealing with (1) the extent of As contamination in southeast Asia; (2) human As exposure and risk assessment at the landscape level; and (3) chronic exposure of As from drinking water and its adverse health impacts, as well as 17 original articles. The contents are grouped into six sections as outlined in the following sections.

Overview of the extent of As contamination from a southeast Asian perspective

The adverse impact of As contamination of groundwater on human health has been reported worldwide, particularly in Asian countries. Since the discovery of chronic As-induced skin disorders in the state of West Bengal, India, in 1984 (Saha 1984; Guha Mazumder et al. 1988; Das et al. 1996; Bhattacharya et al. 1997), the crisis has intensified following discoveries in the adjoining country, Bangladesh (Dhar et al. 1997; Mukherjee and Bhattacharya 2001; Bhattacharya et al. 2002a, b, 2006; Naidu et al. 2006). Fot the past 2 decades, natural occurrences of As have been discovered in several other countries in southeast Asia, where As contamination has become more widespread in recent years. The first paper by Rahman et al. (2008a) presents an overview of the As crisis in the southeast Asian region where groundwater is contaminated with naturally occurring As; about 100 million people in this region are estimated to be at risk, and so far some 700,000 people are known to have been affected by As-related diseases. Despite investments exceeding many millions of dollars, there are still substantial knowledge gaps about the prevalence and impact of As, notably in evaluating the epidemiological impacts, the temporal variability of As concentrations, social factors, identification of the affected patients and their treatment, etc. Among the major concerns is the fact that many researchers from different countries have been conducting research in southeast Asia, but there has been a general lack of coordination, which has often led to duplication, as well as a lack of proper follow-up on the rationale for these individual works. Thus, there is urgent need to coordinate these various efforts to improve the efficacy of research outcomes. Further research is needed to improve the field testing and monitoring of the drinking water sources, to develop new treatments for chronic As toxicity and to find new sources of safe drinking water (Jakariya et al. 2007a, b; van Geen et al. 2005; von Brömssen et al. 2007).

Hydrogeochemical constraints of As in groundwater and monitoring: examples from Bangladesh

Natural cycling of As is caused by the interactions of natural water with sediments, soils and bedrocks and often is influenced by atmospheric deposition. Weathering and leaching of geological formations and mine wastes have resulted in elevated concentrations of As in natural waters in several areas. Mobility of As is constrained in the surface water because of the prevalence of oxic conditions. However, reducing conditions caused by the aquifers lead to the mobilisation of As, thereby increasing the risk of groundwater contamination. The widely reported occurrences of natural As in groundwater in different parts of the world and their levels of concentrations vary significantly depending on the redox characteristics of groundwater and the lithological characteristics of the aquifers (Bhattacharya et al. 2002a, b, 2006; Bhattacharya and Welch 2000; Naidu et al. 2006; Nriagu et al. 2007; Hasan et al. 2007, 2008 in press). It is thus important to determine the As levels in contaminated water sources to ensure the quality of groundwater as a drinking water source using the field test kits and to establish their reliability (Jakariya et al. 2007a, b).

The first article in this section deals with the groundwater chemistry and its implication on the 
mobilisation of As with an example from the Holocene flood plains of south-central Bangladesh (Bhattacharya et al. 2008). A comparative study of As enrichment in three alluvial aquifers in the Sonargaon, Chandina and Sirajdikhan areas in Narayanganj Comilla and Munshiganj districts in southcentral Bangladesh reveal considerable variation in the hydrogeochemical and redox characteristics. The study indicated that while the redox processes were driven by the biogeochemical processes, there was a distinct variability in the concentration of DOC, $\mathrm{NH}_{4}{ }^{+}$and $\mathrm{HCO}_{3}{ }^{-}$with dissolved $\mathrm{As}, \mathrm{Fe}$ and $\mathrm{Mn}$ in the groundwater (Bhattacharya et al. 2008). It has been suggested that the dissolved As may be decoupled from dissolved Mn while it is re-adsorbed onto the $\mathrm{Mn}(\mathrm{IV})$ in solid phase as well as from dissolved $\mathrm{Fe}$ when precipitation of $\mathrm{Fe}(\mathrm{II})$ minerals controls the aqueous concentrations of Fe. In addition, several other concurrent redox processes may constrain the mobilisation of As in the BD aquifers.

Once detected in groundwater, arsenic needs to be addressed with regular monitoring. Field test kits have been largely used in recent years in Bangladesh, West Bengal (India) and elsewhere in the world in order to establish the drinking water quality. Most of the kits are based on the reaction of arsine gas with some chemical agent to form a coloured complex; the intensity of the colour is visually compared with a standard colour code chart or measured electronically to determine the concentration of As in the water sample. The following paper in this section by Arora et al. (2008) identifies the research gaps for future work to enhance the accuracy and reliability of test results produced by the field test kits.

Chemistry and bioavailability of inorganic As in soils

The bioavailability of As in the soil environment is largely governed by its adsorption-desorption reactions with soils and sediments. This section comprises three articles dealing with the influence of ionic strength, index cations and competing anions on arsenate $\left(\mathrm{As}^{\mathrm{V}}\right)$ adsorption-desorption kinetics in soils based on laboratory studies (Smith and Naidu 2008); the sorption-desorption characteristics of As have been investigated in four typical soils in Bangladesh, subjected to irrigation with As-contaminated groundwater (Naidu et al. 2008) and the accumulation of $\mathrm{Fe}$ and As in the Chandina Alluvium of the Lower Delta Plain, southeastern Bangladesh (Zahid et al. 2008).

Laboratory experiments indicated that the adsorption kinetics for arsenate $\left(\mathrm{As}^{\mathrm{V}}\right)$ in all the treatments were initially fast with $58-91 \%$ of $\mathrm{As}^{\mathrm{V}}$ adsorbed during the first $15 \mathrm{~min}$. The presence of phosphate increased the amount of $\mathrm{As}^{\mathrm{V}}$ desorbed by $17 \%$, but other changes in the solution ionic strength or index cation had little effect on the desorption of $\mathrm{As}^{\mathrm{V}}$ (Smith and Naidu 2008). Despite the low total soil As content in the analysed soil samples from Laksham district of Bangladesh, the concentration of pore water As of soils freshly irrigated with As-contaminated groundwater ranged from 0.01 to $0.1 \mathrm{mgl}^{-1}$ (Naidu et al. 2008) However, when these soils were allowed to dry, the concentration of As in pore water decreased to undetectable levels. Comparison of Bangladeshi soils with some of the strongly weathered long-term Ascontaminated soils from Queensland, Australia, showed much greater release of As in water extracts from the Australian soils because of a higher concentration of As in the Australian soils (Smith et al. 1999, 2002). Batch studies showed appreciable capacity for both $\mathrm{As}^{\mathrm{V}}$ and $\mathrm{As}{ }^{\mathrm{III}}$ sorption, with $\mathrm{As}^{\mathrm{V}}$ being retained in much greater concentrations than $\mathrm{As}^{\mathrm{III}}$. The study carried out on the Chandina alluvium of southeastern Bangladesh (Zahid et al. 2008) revealed that the accumulation of $\mathrm{Fe}, \mathrm{Mn}$ and As occurred within $2.5 \mathrm{~m}$ below ground level and was characterised by distinct orange-brown horizons occurring within $1 \mathrm{~m}$ of contact with aerated (yellow-brown) and the grey water-saturated sediment. Dynamics of $\mathrm{Fe}$ were reflected by the precipitation of the ferric oxyhydroxides due to the oxidation of reduced iron in pore waters at the upper part of the saturated zone while exposed to air. Hydrous Fe-oxides with high specific surface area have a high adsorption capacity that absorbs the bulk of As (up to $280 \mathrm{mg} / \mathrm{kg}$ ) from the reduced pore waters. The redox gradient that characterises the transition of saturated and unsaturated sediments also indicates accumulation of manganese oxides in the oxidized sediment. The final article in this section (Smith et al. 2008a) deals with the potential human exposure of As due to the incidental soil ingestion due to a historical legacy of contaminated sites. The study indicated an increased bioaccessibility of As with decreasing particle size and should thus be reconsidered if the ingested material is enriched with small particle fractions particularly found in the household dust. 
Extraction of As species from soils and plants

The extraction procedure is important for determining the speciation of As in soils, as the extraction efficiencies vary considerably in various soil types (Garcia-Manyes et al. 2002) depending on the binding characteristics of As with the different soil minerals. Since bioavailability and speciation of As are critical factors for the assessment of human health risks, there is a need to develop a reliable standard extraction method for the speciation of As in plant tissue used as human food. This section comprises two articles that deal with (1) a novel microwaveassisted extraction method for As speciation of soils, based on extraction with phosphate solutions, including orthophosphoric acid, ammonium dihydrogen orthophosphate and ammonium hydrogen orthophosphate (Rahman et al. 2008b) and (2) the efficacy of ammonium dihydrogen phosphate and protein solution for the extractability of As from two different species of spinach (by Rahman F et al. 2008).

Based on the results of extractable As (Rahman et al. 2008b), it has been shown that that the extraction of As species depends on the soil composition, and the speciation results indicated that the adsorption and stability of the As species are highly dependent on the $\mathrm{Fe}, \mathrm{Al}$ and $\mathrm{Mn}$ concentrations in the soil. The other study by Rahman F et al. (2008) illustrated that the microwave-assisted technique with protein-extracting solution achieved an excellent separation and speciation of all As species in the spinach, accounting for $76-114 \%$ extractability.

Arsenic speciation uptake mechanisms and toxicity of As by plants and microbiota

The three articles presented in this section deal with (1) the influence of the concentration and speciation of $\mathrm{As}^{\mathrm{III}}$ and $\mathrm{As}^{\mathrm{V}}$ on the growth, uptake and translocation of As in vegetable crops (silverbeet and amaranth) based on a greenhouse study (Rahman and Naidu 2008); (2) speciation of As in common Australian garden vegetables grown hydroponically with As-contaminated irrigation water to determine the uptake and species of As present in vegetable tissue as an important consideration because of the varying toxicity of different As species (Smith et al. 2008b); (3) a study on the toxicity of $\mathrm{As}^{\mathrm{III}}$ and $\mathrm{As} \mathrm{V}^{\mathrm{V}}$, alone and/or in combination, to the Cladoceran
Daphnia carinata and the influence of microbial transformation in natural waters (He et al. 2008).

Investigations on As uptake by vegetable crops (Amaranthus gangeticus and Beta vulgaris) as affected by As speciation (As ${ }^{\mathrm{III}}$ and $\mathrm{As}^{\mathrm{V}}$ ) and their concentrations in nutrient solutions revealed that both $\mathrm{As}^{\mathrm{V}}$ and $\mathrm{As}{ }^{\mathrm{III}}$ are phytotoxic to these crops, with the latter being five times more toxic (Rahman and Naidu 2008). The uptake of As in shoots increased in the presence of high concentrations of $\mathrm{As}^{\mathrm{V}}$ in the nutrient solution and exceeded the WHO recommended limit for food stuffs. Iron treatment with $0.5 \mathrm{mg}$ $\mathrm{NaFe}(\mathrm{III}) \mathrm{EDTA} / \mathrm{L}$ dose decreased silverbeet As uptake by $45 \%$ given its affinity to bind As at the root surface or root rhizosphere and so restrict As translocation to the shoots. Studies by Smith et al. (2008b) on the common Australian garden vegetables grown hydroponically with As-contaminated irrigation water revealed the highest concentrations of total As in the roots of all vegetables. The concentration of As was considerably lower in the aerial portions of the plants. Elevated As in vegetable roots suggests the possible complexation of As by phytochelatins. In a different study, He et al. (2008) indicated that As ${ }^{\text {III }}$ and $\mathrm{As}^{\mathrm{V}}$ can interact either synergistically or additively, resulting in an increase in the overall toxicity of the mixture compared to individual As species. The indigenous micro-organisms in natural water might also play a significant role in the transformation of As, thereby influencing the toxicity of As in recipient waters. This study thus indicates that the influence of the As species needs to be considered for developing water quality guidelines.

Assessment of chronic As exposure and associated human health risks

The assessment of the bioavailability of As from the contaminated land and water environment is a crucial parameter for estimating exposure risks (Naidu et al. 2006; Correll et al. 2006). This section comprises seven articles dealing with a wide spectrum of topics, ranging from (1) an impressive review of human As exposure and assessment of the associated risks at a landscape level (Khan et al. 2008a, b); (2) a review of current state-of-the-art research conducted on the adverse health effects on humans exposed to Ascontaminated water in Bangladesh (Rahman et al. 2008c); (3) the presentation of an effective design for 
an assessment tool, the dietary survey framework (DSF), to analyse the total dietary intake of As and demonstrate its application in Bangladesh (Khan et al. 2008c), (4) preliminary findings on total dietary As intake by implementation of a food frequency questionnaire in Bangladesh; (5) estimation of the daily intake of As from rice in As-affected villages in Bangladesh where groundwater is used for agricultural irrigation (Rahman et al. 2008d); (6) in vivo assessment of As bioavailability in swine as an applicable model for human health risk assessment (Rees et al. 2008); (7) a study of As interactions with lipid particles containing iron based on a sequestration of toxins and pathogens by lipid particles (Rahman, Mahbub M et al. 2008).

The focus of more recent studies has been to perform risk assessment at the landscape level involving the use of biomarkers to identify and quantify the appropriate health problems and large surveys of human dietary patterns, supported by analytical approaches to quantify the levels of As in different contaminant matrices to quantify exposure. The current paradigm on environmental risk assessment worldwide is shifting from a qualitative to quantitative approach, prompting researchers to direct future efforts towards the creation of a common platform by integrating GIS, statistics, chemistry, human health scenarios and other dynamic models for the quantitative estimation of the human health risk at the landscape level. The accurate assessment of dietary intake as a pattern is important for the determination of total dietary As exposure in the As-affected regions of Bangladesh and also for application worldwide. A food frequency questionnaire (FFQ) (Khan et al. 2008c) can be used for generating quantified data on the sources of food, the frequency and the daily amount of food consumption by the exposed population. The preliminary results of a FFQ survey are presented in the article by Khan et al. (2008b), which demonstrates that this technique can be used in rural areas as a tool to assess As exposure and the associated human health risks and also can be scaled up in several other contaminated regions of Bangladesh and several other affected regions. The study by Rahman et al. (2008d) revealed that the daily intake of As from rice and from drinking water was $888.4 \mu \mathrm{g}$ and $706.4 \mu \mathrm{g}$, respectively, putting the people at risk of chronic As exposure. In vivo assessment of As is envisaged as an appropriate model applicable to human health risk assessment using swine because of their remarkable similarity to humans in terms of physiology and As metabolism (Rees et al. 2008). This kind of study could be used to estimate exposure for human health risk assessment. Rahman, Mahbub M et al. (2008) present an interesting result from the study on As interactions with invertebrate and vertebrate lipid particles that are associated with proteins that may lead to detoxification by cell-free or cellular sequestration mechanisms. The final paper by Bencko et al. (2008) deals with the assessment of ecological and human health consequences of environmental pollution caused by burning local coal in the power plants with the emission of exceedingly high concentrations of As (900-1,500 g/ ton). Exposure assessment of the local population of the Prievidza district, Central Slovakia, revealed a positive correlation between the cumulative human exposure to As and incidence of non-melanoma skin cancer (NMSC). However, the overall ecological effects of the environmental emissions from the power plants were manifested by the mass extinction of honey-bee colonies in the region. Biological monitoring is thus important and necessary for an overall assessment of environmental As contamination.

\section{Conclusions}

Arsenic contamination of water supplies is a global problem. Past anthropogenic practices have released large amounts of As into the environment and caused contamination of groundwater resources, usually at relatively small scales. In many areas of the world, biogeochemical processes have resulted in the release of naturally occurring As into groundwater; in some cases, large regions are affected. The adverse impact of As on human health has been documented, and the current state-of-the-art knowledge reveals that As can also have a negative effect on agricultural production systems. Remediation of As-contaminated water is therefore critical. Phytoremediation is one potentially cost-effective means for removing As from water. Natural geologic materials have also been shown to be effective in removing As from water. Solving the problem of As-contamination will require a variety of approaches from different fields of research. Burning high As coal is a natural hazard for populations living in the vicinity of such facilities, and thus 
environmental risk assessment of such regions must consider an integrated and multidisciplinary approach.

We sincerely hope that these articles are of considerable interest to the readers. They reflect our most up-to-date understanding of various inter-disciplinary facets of the problem of As in the environmental realm, mechanisms of mobilisation in groundwater, the fate of As in the agricultural systems, biogeochemical interactions and the assessment of human implications. We believe that discussions during the symposium significantly improved our understanding of the global problem of As contamination for land and water resource management, which is vital for millions of people across the world.

Acknowledgments This Special Supplement would not be complete without expressing our sincere and deep gratitude to the Centre for Environmental Risk Assessment and Remediation (CERAR) at the University of South Australia. The editors acknowledge the financial support of the Australian Centre for International Agricultural Research (ACIAR) and AusAID, which helped us to make a substantial contribution to the prevention of As poisoning in Bangladesh. PB thanks the Swedish International Development Cooperation Agency (Sida), Swedish Research Council (VR) and the MISTRA for support to ongoing research grants for research and implementation of sustainable As mitigation in Bangladesh. We appreciate the support from all our anonymous reviewers, for their valuable time and their constructive reviews of the manuscripts submitted for this special issue. We wish to express our sincere thanks to those who helped us to maintain the high quality of the papers in this volume. We would like to express our sincere thanks to Ms. Betty van Herk and Ms. Pauline Lichtveld, Springer SBM NL, who were responsible for this special supplement of the Journal of Environmental Geochemistry and Health, for their help and patience during the finalisation of this volume.

\section{References}

Arora, M., Megharaj, M., \& Naidu, R. (2008). Arsenic testing field kits: some considerations and recommendations. Environmental Geochemistry and Health. (this volume). doi: 10.1007/s10653-008-9231-4.

Bencko, V., Ramen, J., Fabiánová, E., Penek, J., \& Jakubis, M. (2008). Ecological and human health risk aspects of burning arsenic rich coal. Environmental Geochemistry and Health. (this volume). doi: 10.1007/s10653-008-9224-3.

Bhattacharya, P., Welch, A. H., (2000). Arsenic in groundwaters of sedimentary aquifers. Abstract Volume, PreCongress Workshop (Bwo 10). http://www.lwr.kth.se/ Personal/personer/bhattacharya_prosun/Rio_abstract.pdf.

Bhattacharya, P., Ahmed, K. M., Hasan, M. A., Broms, S., Fogelström, J., Jacks, G., et al. (2006). Mobility of arsenic in groundwater in a part of Brahmanbaria district, NE Bangladesh. In R. Naidu, E. Smith, G. Owens, P. Bhattacharya, \& P. Nadebaum (Eds.), Managing Arsenic in the Environment: From soil to human health (pp. 95-115). Melbourne, Australia: CSIRO Publishing. (ISBN 0643068686).

Bhattacharya, P., Chatterjee, D., \& Jacks, G. (1997). Occurrence of arsenic contaminated groundwater in alluvial aquifers from Delta Plains, Eastern India: Options for safe drinking water supply. International Journal of Water Resources Management, 13, 79-92.

Bhattacharya, P., Frisbie, S. H., Smith, E., Naidu, R., Jacks, G., \& Sarkar, B. (2002a). Arsenic in the environment: A global perspective. In B. Sarkar (Ed.), Handbook of Heavy Metals in the Environment (pp. 145-215). New York: Marcell Dekker Inc.

Bhattacharya, P., Hasan, M. A., Sracek, O., Smith, E., Ahmed, K. M., von Brömssen, M., Huq, S. M. I., \& Naidu, R. (2008). Groundwater chemistry and arsenic mobilisation in the Holocene flood plains in South-central Bangladesh. Environmental Geochemistry and Health. (this volume). doi: 10.1007/s10653-008-9230-5.

Bhattacharya, P., Jacks, G., Ahmed, K. M., Khan, A. A., \& Routh, J. (2002b). Arsenic in groundwater of the Bengal Delta Plain aquifers in Bangladesh. Bulletin of Environmental Contamination and Toxicology, 69, 538-545.

Correll, R., Huq, S. M. I., Smith, E., Owens, G., \& Naidu, R. (2006). Dietary intake of arsenic from crops: Overview from the Bangladesh study. In R. Naidu, E. Smith, G. Owens, P. Bhattacharya, \& P. Nadebaum (Eds.), Managing Arsenic in the Environment: From soil to human health (pp. 255-271). Melbourne, Australia: CSIRO Publishing. (ISBN 0643068686).

Das, D., Samanta, G., Mandal, B. K., Roy Chowdhury, T., Chanda, C. R., Chowdhury, P. P., et al. (1996). Arsenic in groundwater in six districts of West Bengal, India. Environmental Geochemistry and Health, 18, 5-15.

Dhar, R. K., Biswas, B. K., Samanta, G., Mandal, B. K., Chakraborti, D., Roy, S., et al. (1997). Groundwater arsenic calamity in Bangladesh. Current Science, 73(1), 48-59.

Garcia-Manyes, S., Jimenez, G., Padro, A., Rubio, R., \& Rauret, G. (2002). Arsenic speciation in contaminated soils. Talanta, 58, 97-109.

Guha Mazumder, D. N., Chakraborty, A. K., Ghosh, A., Gupta, J. D., Chakraborty, D. P., Dey, S. B., et al. (1988). Chronic arsenic toxicity from drinking tubewell water in rural West Bengal. Bulletin of the World Health Organization, 66, 499-506.

Hasan, M. A., Ahmed, K. M., Sracek, O., Bhattacharya, P., von Brömssen, M., Broms, S., et al. (2007). Arsenic in shallow groundwater of Bangladesh: Investigations from three different physiographic settings. Hydrogeology Journal, $15,1507-1522$.

Hasan, M. A., von Brömssen, M., Bhattacharya, P., Ahmed, K. M, Sikder, A. M., Jacks, G., \& Sracek, O. (2008). Geochemistry and mineralogy of shallow alluvial aquifers in Daudkandi upazila in the Meghna flood plain, Bangladesh. Environmental Geology. doi:10.1007/s00254-0081319-8.

He, W., Megharaj, M., \& Naidu, R. (2008). Toxicity of tri- and penta-valent arsenic, alone and in combination, to the Cladoceran Daphnia carinata: the influence of microbial 
transformation in natural waters. Environmental Geochemistry and Health. (this volume). doi: 10.1007/s10653-008-9239-9.

Jakariya, M., Vahter, M., Rahman, M., Wahed, M. A., Hore, S. K., Bhattacharya, P., et al. (2007a). Screening of arsenic in tubewell water with field test kits: Evaluation of the method from public health perspective. Science of the Total Environment, 379, 167-175. doi:10.1016/j.scitotenv.2006. 11.053 .

Jakariya, M., von Brömssen, M., Jacks, G., Chowdhury, A. M. R., Ahmed, K. M., \& Bhattacharya, P. (2007b). Searching for sustainable arsenic mitigation strategy in Bangladesh: Experience from two upazilas. International Journal of Environment and Pollution, 31(3/4), 415-430.

Khan, N. I., Owens, G., Bruce, D., \& Naidu, R. (2008a). Human arsenic exposure and risk assessment at the landscape level: A review. Environmental Geochemistry and Health.. (this volume). doi: 10.1007/s10653-0089240-3.

Khan, N. I., Bruce, D., Naidu, R., \& Owens, G. (2008b). Implementation of food frequency questionnaire for the assessment of total dietary arsenic intake in Bangladesh: Part-B-Preliminary Findings. Environmental Geochemistry and Health. (this volume). doi: 10.1007/s10653008-9232-3

Khan, N. I., Owens, G., Bruce, D., \& Naidu, R. (2008c). An effective dietary survey framework for the assessment of total dietary arsenic intake in Bangladesh: Part-A-FFQ Design. Environmental Geochemistry and Health. (this volume). doi:10.1007/s10653-008-9234-1.

Mukherjee, A. B., \& Bhattacharya, P. (2001). Arsenic in groundwater in the Bengal Delta Plain: Slow poisoning in Bangladesh. Environmental Review, 9(3), 189-220.

Naidu, R., Smith, E., Huq, I., \& Owens, G. (2008). Sorption and bioavailability of arsenic in selected Bangladesh soils. Environmental Geochemistry and Health. (this volume). doi:10.1007/s10653-008-9229-y.

Naidu, R., Smith, E., Owens, G., Bhattacharya, P., \& Nadebaum, P. (2006). Managing arsenic in the environment: from soil to human health (pp. 747). Collingwood, Melbourne: CSIRO Publications.

Nriagu, J. O., Bhattacharya, P., Mukherjee, A. B., Bundschuh, J., Zevenhoven, R., Loeppert, R. H. (2007). Arsenic in soil and groundwater: an introduction. In P. Bhattacharya, A. B. Mukherjee, J. Bundschuh, R. Zevenhoven \& R. H. Loeppert (Eds.), Arsenic in soil and groundwater environment: Biogeochemical interactions, health effects and remediation, trace metals and other contaminants in the environment (Series Editor Nriagu, J. O.) (Vol. 9, pp. 360). Amsterdam, The Netherlands: Elsevier.

Rahman, F., \& Naidu, R. (2008). The influence of arsenic speciation ( $\mathrm{As}{ }^{\mathrm{III}}$ and $\mathrm{As}^{\mathrm{V}}$ ) and concentration on the growth, uptake and translocation of arsenic in vegetable crops (silverbeet and amaranth)—greenhouse study. Environmental Geochemistry and Health. (this volume). doi: 10.1007/s10653-008-9241-2.

Rahman, F., Chen, Z. L., \& Naidu, R. (2008). A comparative study of the extractability of arsenic species from silverbeet and amaranth vegetables. Environmental Geochemistry and Health. (this volume). doi:10.1007/ s10653-008-9225-2.
Rahman, M. M., Naidu, R. \& Bhattacharya, P. (2008a). Arsenic contamination in groundwater in the Southeast Asia region. Environmental Geochemistry and Health. (this volume). doi:10.1007/s10653-008-9233-2.

Rahman, M. M., Chen, Z. L., \& Naidu, R. (2008b). Extraction of arsenic species in soils using microwave assisted extraction detected by ion chromatography coupled to inductively coupled plasma mass spectrometry. Environmental Geochemistry and Health. (this volume). doi: 10.1007/s10653-008-9227-0.

Rahman, M. M., Ng, J. C., \& Naidu, R. (2008c). Chronic exposure of As via drinking water and its adverse health impacts on humans. Environmental Geochemistry and Health. (this volume). doi: 10.1007/s10653-008-9235-0.

Rahman, M. M., Owens, G., \& Naidu, R. (2008d). Arsenic levels in rice grain and assessment of daily dietary intake of arsenic from rice in arsenic-contaminated regions of Bangladesh-implications to groundwater irrigation. Environmental Geochemistry and Health. (this volume). doi: 10.1007/s10653-008-9238-x.

Rahman, Mahbub, M., Rahman, F., Sansom, L., Naidu, R., \& Otto Schmidt, O. (2008). Arsenic interactions with lipid particles containing iron. Environmental Geochemistry and Health. (this volume). doi:10.1007/s10653-0089236-z.

Rees, M., Sansom, L., Rofe, A., Juhasz, A. L., Smith, E., Weber, J., Naidu, R., \& Kuchela T. (2008). Principles and application of an in vivo swine assay for the determination of arsenic bioavailability in contaminated matrices. Environmental Geochemistry and Health. (this volume). doi:10.1007/s10653-008-9237-y.

Saha, K. C. (1984). Melanokeratosis from arsenic contaminated tubewell water. Indian Journal of Dermatology, 29, 37-46.

Smith, E., Weber, J., \& Juhasz, A. L. (2008a). Arsenic distribution and bioaccessibility across particle fractions in historically contaminated soils. Environmental Geochemistry and Health. (this volume). doi:10.1007/s10653009-9249-2.

Smith, E., Juhasz, A. L., \& Weber, J. (2008b). Arsenic uptake and speciation in vegetables grown under greenhouse conditions. Environmental Geochemistry and Health. (this volume). doi:10.1007/s10653-008-9242-1.

Smith, E., \& Naidu, R. (2008). Chemistry of inorganic arsenic in soils: Kinetics of arsenic adsorption-desorption. Environmental Geochemistry and Health. (this volume). doi: 10.1007/s10653-008-9228-z.

Smith, E., Naidu, R., \& Alston, A. M. (1999). Chemistry of arsenic in soils: I. Sorption of arsenate and arsenite by four Australian soils. Journal of Environment Quality, 28, 1719-1726.

Smith, E., Naidu, R., \& Alston, A. M. (2002). Chemistry of inorganic arsenic in soils: II. Effect of phosphorus, sodium, and calcium on arsenic sorption. Journal of Environmental Quality, 31, 557-563.

van Geen, A., Cheng, Z., Seddique, A. A., Hoque, M. A., Gelman, A., Graziano, J. H., et al. (2005). Reliability of a commercial kit to test groundwater for arsenic in Bangladesh. Environmental Science and Technology, 39(1), 299-303.

von Brömssen, M., Jakariya, M., Bhattacharya, P., Ahmed, K. M., Hasan, M. A., Sracek, O.,Jonsson, L., Lundell, L., \& 
Jacks, G. (2007). Targeting low-arsenic aquifers in Matlab Upazila, Southeastern Bangladesh. The Science of the Total Environment, 379(2-3), 121-132.

Zahid, A., Hassan, M. Q., Breit, G. N. K., Balke, D., \& Flegr,

M. (2008). Accumulation of iron and arsenic in the
Chandina Alluvium of the Lower Delta Plain, Southeastern Bangladesh. Environmental Geochemistry and Health. (this volume). doi:10.1007/s10653-008-9226-1. 